\title{
The Implementation of Inclusive Education in Regencies/Cities in Indonesia
}

\author{
Munawir Yusuf, Erma Kumalasari, Mahardika Supratiwi \\ Special Education \\ Sebelas Maret University \\ Surakarta, Indonesia \\ munawir_uns@yahoo.co.id
}

\begin{abstract}
This study aimed to investigate the implementation of inclusive education at the working group level in the regencies/cities in Indonesia. This study used qualitative descriptive approach with a focus on implementing the inclusion working group in the regency/city. The subject of this study was sixteen working groups in the territory of Indonesia. All of the working groups' chairmen were 20 people as research samples. The data collection technique used was questionnaires that had been tested for its validity and reliability. The collected data were tabulated to calculate the percentage, and then were described to interpret the results of the data collection. The results of the study stated that the implementation of the inclusion working group in Indonesia has been applied in a proper way as seen from the average achievement score of implementation of inclusive education which was included in the good category $\mathbf{( 7 5 . 1 8 \% )}$.
\end{abstract}

Keywords-inclusive education; implementation; inclusion working group.

\section{INTRODUCTION}

The issue of inclusive education has become an important theme in educational topic in Indonesia. It is not only because it has been already a part of international problems discussed by developed countries, which developing countries try to participate in ratifying various world convention to actualize educational rights for all children, but also because the country has been more aware to develop good quality of education. It is impossible to behave a discriminatory manner to only prioritize those who are 'normal' and/or who have potential above average or extraordinary.

In a broad context, inclusive education can be interpreted as a form of educational reform that emphasizes antidiscrimination attitudes, opportunities for rights, justice and expansion of access to education for all, improvement of the education quality, strategic efforts in completing 9-year compulsory education, and efforts to change people's attitudes for children with special needs [1]. Reference [2] stated that inclusion is an approach that pays attention to how to transform the education system so that it can respond to diversity and see it more as a challenge and enrichment in the learning environment than a problem.
Support for Inclusive Education in Indonesia, indicated by the regulation of Minister of National Education Regulation No. 70 of 2009 on Inclusive Education for children who have abnormalities and have intelligence potential and/or special talents [3]. As a result, inclusive education is implemented at every level of education; a regulation that supports inclusive education is the Circular Letter of the Directorate General of Basic Education Ministry of Education Number. 380/C.C6/MN/2003 January 20, 2003: "Each regency/city is required to organize and develop inclusive education in at least 4 (four) schools consisting of; elementary, middle school, high school, vocational high school"[4].

In addition, to implement inclusive education, supporting system is essential to accelerate the fulfillment of access and quality education for all. The support system can be in the form of clear support from the Regional Government (Province and Regency/City) on inclusive education, for example in the form of "Regulations of Province/Regency/City" on inclusive eeducation, facilities and infrastructure support, financia, staffs (educators and education personnel) and support from supporting institutions [5]. Supporting institutions include the Inclusive Education Working Group (National, Provincial, Regency/City Level), Resource Centers for public schools that organize inclusive education, professional associations of teachers, principals, and school supervisors such as SD/SLB Clusters. (KKG, KKKS, and KKPS), MGMP, MKKS, and MKPS). Reference [6] also stated that one of the factors influencing inclusive education is the presence of support groups that collaborate with schools and other parties so that they are expected to fulfill the needs of students in schools and achieve inclusive education goals.

In Province/Regency/City in Indonesia, the group was formed in a team which is often called the Inclusive Education Working Group (Inclusion Working Group) [5]. Reference [5] stated that the Working Group on Inclusive Education (Inclusion Working Group) has the task of preparing work programs for inclusive education, carrying out socialization and fostering the implementation of inclusive education, and carrying out monitoring and evaluation of inclusive education. Based on this description, the purpose of this study was to examine to what the extent inclusive education is carried out at 
the working group level and the assessment of the Inclusion Working Group all over Indonesia is carried out.

\section{METHOD}

This study used qualitative descriptive approach with a focus on the implementation of the Inclusion Working Group in the Regency/City. The subject of this study was sixteen Inclusion Working Groups in the territory of Indonesia. All inclusion working groups chairmen were 20 people as research samples. The data collection technique used questionnaires that had been tested for its validity and reliability. The data that has been collected was tabulated to calculate the percentage, and then were described to interpret the results of the data collection.

\section{RESULT AND DISCUSSION}

Based on the results of data collection on the implementation of inclusive education that has been carried out by working groups in regencies, it is obtained as follow:

\section{A. Human Resource of Inclusive Education Organizer Capacity Development Program}

Human resource of inclusive education organizer capacity development program are presented in Table .

TABLE I. HR CAPACITY BUILDING PROGRAM OF INCLUSIVE EDUCATION ORGANIZERS

\begin{tabular}{|l|l|l|l|l|l|}
\hline No & $\begin{array}{l}\text { Regency/ } \\
\text { City }\end{array}$ & $\begin{array}{c}\text { Achievement } \\
(\%)\end{array}$ & No & $\begin{array}{l}\text { Regency/ } \\
\text { City }\end{array}$ & $\begin{array}{c}\text { Achievement } \\
(\%)\end{array}$ \\
\hline 1 & $\begin{array}{l}\text { Payakum } \\
\text { buh }\end{array}$ & 85.7 & 9 & $\begin{array}{l}\text { Kulonpro } \\
\text { go }\end{array}$ & 57.1 \\
\hline 2 & $\begin{array}{l}\text { Bukitting } \\
\text { gi }\end{array}$ & 81.0 & 10 & Pacitan & 71.4 \\
\hline 3 & Padang & 90.5 & 11 & Magetan & 61.9 \\
\hline 4 & Wonogiri & 81.0 & 12 & Banjar & 66.7 \\
\hline 5 & Boyolali & 61.9 & 13 & $\begin{array}{l}\text { Banjar } \\
\text { Baru }\end{array}$ & 66.7 \\
\hline 6 & Salatiga & 66.7 & 14 & $\begin{array}{l}\text { Central } \\
\text { Lombok }\end{array}$ & 85.7 \\
\hline 7 & $\begin{array}{l}\text { Karangan } \\
\text { yar }\end{array}$ & 71.4 & 15 & $\begin{array}{l}\text { East } \\
\text { Lombok }\end{array}$ & 71.4 \\
\hline 8 & $\begin{array}{l}\text { Gunung } \\
\text { Kidul }\end{array}$ & 100.0 & 16 & Ambon & 52.4 \\
\hline Average & \multicolumn{3}{|l}{} \\
\hline
\end{tabular}

Average $=73.2 \%$

Based on Table 1 above, it can be seen that from the 16 regencies/cities as the sample of the study, the average achievement of the program of human resource of inclusive education organizer capacity development was $73.2 \%$. Gunung Kidul Regency had the highest achievement (100\%); on the other hand, Ambon City had the lowest achievement (52.4\%).

\section{B. Program on Policy and Regulation on the Implementation of Inclusive Education}

Program on policy and regulation on the implementation of inclusive education is presented in Table 2.
TABLE II. PROGRAM ON POLICY AND REGULATION ON THE IMPLEMENTATION OF INCLUSIVE EDUCATION

\begin{tabular}{|l|l|l|l|l|l|}
\hline No & \multicolumn{1}{|c|}{$\begin{array}{c}\text { Regency } \\
\text { /City }\end{array}$} & $\begin{array}{c}\text { Achievement } \\
(\%)\end{array}$ & No & $\begin{array}{l}\text { Regency/ } \\
\text { City }\end{array}$ & $\begin{array}{c}\text { Achievement } \\
(\%)\end{array}$ \\
\hline 1 & Payakumbuh & 80.0 & 9 & $\begin{array}{l}\text { Kulonpro } \\
\text { go }\end{array}$ & 100.0 \\
\hline 2 & Bukittinggi & 46.7 & 10 & Pacitan & 13.3 \\
\hline 3 & Padang & 100.0 & 11 & Magetan & 80.0 \\
\hline 4 & Wonogiri & 66.7 & 12 & Banjar & 53.3 \\
\hline 5 & Boyolali & 53.3 & 13 & $\begin{array}{l}\text { Banjar } \\
\text { Baru }\end{array}$ & 66.7 \\
\hline 6 & Salatiga & 80.0 & 14 & $\begin{array}{l}\text { Central } \\
\text { Lombok }\end{array}$ & 73.3 \\
\hline 7 & Karanganyar & 60.0 & 15 & $\begin{array}{l}\text { East } \\
\text { Lombok }\end{array}$ & 86.7 \\
\hline 8 & Gunung Kidul & 100.0 & 16 & Ambon & 60.0 \\
\hline \multicolumn{4}{|l|}{ Average $=70 \%$} & \multicolumn{4}{l}{} \\
\hline
\end{tabular}

The template is designed so that author affiliations are not repeated each time for multiple authors of the same affiliation. Please keep your affiliations as succinct as possible (for example, do not differentiate among departments of the same organization). This template was designed for two affiliations.

\section{Partnership Developmant Program through Network Strengthening to Create Awareness and Concern for Inclusive Education}

Partnership Development Program through Network Strengthening to Create Awareness and Concern for Inclusive Education is presented in Table 3.

TABLE III. PARTNERSHIP DEVELOPMANT PROGRAM THROUGH NETWORK STRENGTHENING TO CREATE AWARENESS AND CONCERN FOR INCLUSIVE EDUCATION

\begin{tabular}{|l|l|l|l|l|l|}
\hline No & \multicolumn{1}{|c|}{$\begin{array}{c}\text { Regency/ } \\
\text { City }\end{array}$} & $\begin{array}{c}\text { Achievement } \\
(\%)\end{array}$ & No & $\begin{array}{c}\text { Regency/ } \\
\text { City }\end{array}$ & $\begin{array}{c}\text { Achievement } \\
(\%)\end{array}$ \\
\hline 1 & Payakumbuh & 26.7 & 9 & Kulonprogo & 93.3 \\
\hline 2 & Bukittinggi & 73.3 & 10 & Pacitan & 33.3 \\
\hline 3 & Padang & 86.7 & 11 & Magetan & 80.0 \\
\hline 4 & Wonogiri & 93.3 & 12 & Banjar & 73.3 \\
\hline 5 & Boyolali & 80.0 & 13 & $\begin{array}{l}\text { Banjar } \\
\text { Baru }\end{array}$ & 66.7 \\
\hline 6 & Salatiga & 93.3 & 14 & $\begin{array}{l}\text { Central } \\
\text { Lombok }\end{array}$ & 66.7 \\
\hline 7 & Karanganyar & 73.3 & 15 & $\begin{array}{l}\text { East } \\
\text { Lombok }\end{array}$ & 100.0 \\
\hline 8 & Gunung Kidul & 100.0 & 16 & Ambon & 66.7 \\
\hline \multicolumn{2}{|l|}{ Average $=75.4 \%$} & &
\end{tabular}

Based on Table 3 above, it can be seen that from the 16 regencies/cities that were sampled, the average achievement of the partnership developmant program through network strengthening to create awareness and concern for inclusive education was $75.4 \%$. Gunung Kidul Regency and East Lombok Regency had the highest achievement (100\%), otherwise, Payakumbuh District had the lowest achievement (26.7\%). 


\section{Inclusive Education Organizer Introductory Program Inclusive}

Education Organizer Introductory Program is presented in Table 4.

TABLE IV. INCLUSIVE EDUCATION ORGANIZER INTRODUCTORY PROGRAM

\begin{tabular}{|l|l|l|l|l|l|}
\hline No & \multicolumn{1}{|c|}{$\begin{array}{c}\text { Regency } \\
\text { /City }\end{array}$} & $\begin{array}{c}\text { Achieve } \\
\text { ment (\%) }\end{array}$ & No & Regency/City & $\begin{array}{c}\text { Achievement } \\
(\%)\end{array}$ \\
\hline 1 & Payakumbuh & 66.7 & 9 & Kulonprogo & 77.8 \\
\hline 2 & Bukittinggi & 77.8 & 10 & Pacitan & 44.4 \\
\hline 3 & Padang & 100.0 & 11 & Magetan & 77.8 \\
\hline 4 & Wonogiri & 66.7 & 12 & Banjar & 88.9 \\
\hline 5 & Boyolali & 66.7 & 13 & Banjar Baru & 66.7 \\
\hline 6 & Salatiga & 77.8 & 14 & $\begin{array}{l}\text { Central } \\
\text { Lombok }\end{array}$ & 77.8 \\
\hline 7 & Karanganyar & 77.8 & 15 & East Lombok & 100.0 \\
\hline 8 & $\begin{array}{l}\text { Gunung } \\
\text { Kidul }\end{array}$ & 88.9 & 16 & Ambon & 66.7 \\
\hline \multicolumn{5}{|l|}{ Average $=76.4 \%$} \\
\hline
\end{tabular}

Based on Table 4 above, it can be seen that from the 16 regencies/cities that were the sample of the study, the average achievement of the introductory program for inclusive education organizer was $76.4 \%$. Padang City and East Lombok Regency had the highest achievement (100\%) while Pacitan Regency had the lowest achievement (44.4\%).

\section{E. Data, Information and Publication Center Program}

Data, Information and Publication Center Program is presented in Table 5.

TABLE V. DATA, INFORMATION AND PUbliCATION CENTER PROGRAM

\begin{tabular}{|l|l|l|l|l|l|}
\hline No & $\begin{array}{l}\text { Regency/ } \\
\text { City }\end{array}$ & $\begin{array}{c}\text { Achievement } \\
(\%)\end{array}$ & No & \multicolumn{1}{|c|}{$\begin{array}{c}\text { Regency/ } \\
\text { City }\end{array}$} & $\begin{array}{c}\text { Achievement } \\
(\%)\end{array}$ \\
\hline 1 & $\begin{array}{l}\text { Payakum } \\
\text { buh }\end{array}$ & 72.2 & 9 & Kulonprogo & 77.8 \\
\hline 2 & $\begin{array}{l}\text { Bukitting } \\
\text { gi }\end{array}$ & 66.7 & 10 & Pacitan & 44.4 \\
\hline 3 & Padang & 88.9 & 11 & Magetan & 66.7 \\
\hline 4 & Wonogiri & 77.8 & 12 & Banjar & 61.1 \\
\hline 5 & Boyolali & 77.8 & 13 & $\begin{array}{l}\text { Banjar } \\
\text { Baru }\end{array}$ & 66.7 \\
\hline 6 & Salatiga & 83.3 & 14 & $\begin{array}{l}\text { Central } \\
\text { Lombok }\end{array}$ & 66.7 \\
\hline 7 & $\begin{array}{l}\text { Karangan } \\
\text { yar }\end{array}$ & 72.2 & 15 & $\begin{array}{l}\text { East } \\
\text { Lombok }\end{array}$ & 66.7 \\
\hline 8 & $\begin{array}{l}\text { Gunung } \\
\text { Kidul }\end{array}$ & 66.7 & 16 & Ambon & 61.1 \\
\hline \multicolumn{5}{|l|}{ Average $=69.8 \%$} \\
\hline
\end{tabular}

Based on Table 5 above, it can be seen that from the 16 regencies/cities that were the sample of study, the average data center, information, and publication program achievement was 69.8\%. Padang City had the highest achievement (88.9\%) while Pacitan Regency had the lowest achievement (44.4\%).

\section{F. Program for Structuring and Strengthening Inclusive Education Support Systems}

Program for Structuring and Strengthening Inclusive Education Support Systems is presented in Table 6.

TABLE VI. PROGRAM FOR STRUCTURING AND STRENGTHENING INCLUSIVE EDUCATION SUPPORT SYSTEMS

\begin{tabular}{|c|l|c|c|l|c|}
\hline No & \multicolumn{1}{|c|}{$\begin{array}{c}\text { Regency/ } \\
\text { City }\end{array}$} & $\begin{array}{c}\text { Achieve- } \\
\text { ment } \\
(\%)\end{array}$ & No & $\begin{array}{c}\text { Regency/ } \\
\text { City }\end{array}$ & $\begin{array}{c}\text { Achieve- } \\
\text { ment (\%) }\end{array}$ \\
\hline 1 & Payakumbuh & 66.7 & 9 & Kulonprogo & 66.7 \\
\hline 2 & Bukittinggi & 66.7 & 10 & Pacitan & 25.0 \\
\hline 3 & Padang & 100.0 & 11 & Magetan & 83.3 \\
\hline 4 & Wonogiri & 100.0 & 12 & Banjar & 83.3 \\
\hline 5 & Boyolali & 66.7 & 13 & $\begin{array}{l}\text { Banjar } \\
\text { Baru }\end{array}$ & 66.7 \\
\hline 6 & Salatiga & 75.0 & 14 & $\begin{array}{l}\text { Central } \\
\text { Lombok }\end{array}$ & 75.0 \\
\hline 7 & Karanganyar & 50.0 & 15 & $\begin{array}{l}\text { East } \\
\text { Lombok }\end{array}$ & 66.7 \\
\hline 8 & $\begin{array}{l}\text { Gunung } \\
\text { Kidul }\end{array}$ & 91.7 & 16 & Ambon & 66.7 \\
\hline
\end{tabular}

Based on Table 6 above, it can be seen that from the 16 regencies/cities as the sample of the study, the average achievement program for structuring and strengthening the inclusive education support system was $71.9 \%$. Padang City and Wonogiri Regency had the highest achievement (100\%); otherwise, Pacitan Regency had the lowest achievement $(25 \%)$.

\section{G. Documentation and Reporting Program}

Documentation and Reporting Program is presented in Table 7.

TABLE VII. DOCUMENTATION AND REPORTING PROGRAM

\begin{tabular}{|l|l|l|l|l|l|}
\hline No & $\begin{array}{l}\text { Regency/ } \\
\text { City }\end{array}$ & $\begin{array}{c}\text { Achieve- } \\
\text { ment (\%) }\end{array}$ & No & $\begin{array}{c}\text { Regency/ } \\
\text { City }\end{array}$ & $\begin{array}{c}\text { Achieve- } \\
\text { ment (\%) }\end{array}$ \\
\hline 1 & $\begin{array}{l}\text { Payakumb } \\
\text { uh }\end{array}$ & 83.3 & 9 & Kulonprogo & 83.3 \\
\hline 2 & $\begin{array}{l}\text { Bukittingg } \\
\text { i }\end{array}$ & 83.3 & 10 & Pacitan & 66.7 \\
\hline 3 & Padang & 100.0 & 11 & Magetan & 100.0 \\
\hline 4 & Wonogiri & 83.3 & 12 & Banjar & 83.3 \\
\hline 5 & Boyolali & 66.7 & 13 & $\begin{array}{l}\text { Banjar } \\
\text { Baru }\end{array}$ & 66.7 \\
\hline 6 & Salatiga & 83.3 & 14 & $\begin{array}{l}\text { Central } \\
\text { Lombok }\end{array}$ & 66.7 \\
\hline 7 & $\begin{array}{l}\text { Karangany } \\
\text { ar }\end{array}$ & 66.7 & 15 & $\begin{array}{l}\text { East } \\
\text { Lombok }\end{array}$ & 100.0 \\
\hline 8 & $\begin{array}{l}\text { Gunung } \\
\text { Kidul }\end{array}$ & 66.7 & 16 & Ambon & 66.7 \\
\hline Average $=79.2 \%$ & \multicolumn{5}{|l}{} \\
\hline
\end{tabular}

Based on Table 7 above, it can be seen that from the 16 regencies/cities that became the sample of the study, the average achievement of documentation and reporting programs was $79.2 \%$. Padang City, Magetan Regency, and East Lombok Regency had the highest achievement (100\%). 


\section{H. Program of Management for Inclusion Working group} and Grand Design for Inclusive Education Development

Program of Management for Inclusion Working group and Grand Design for Inclusive Education Development is presented in Table 8 .

TABLE VIII. PROGRAM OF MANAGEMENT FOR INCLUSION WORKING GROUP AND GRAND DESIGN FOR INCLUSIVE EDUCATION DEVELOPMENT

\begin{tabular}{|c|l|c|c|l|c|}
\hline No & $\begin{array}{c}\text { Regency/ } \\
\text { City }\end{array}$ & $\begin{array}{c}\text { Achieve- } \\
\text { ment } \\
(\%)\end{array}$ & No & $\begin{array}{c}\text { Regency/ } \\
\text { City }\end{array}$ & $\begin{array}{c}\text { Achieve- } \\
\text { ment (\%) }\end{array}$ \\
\hline 1 & Payakumbuh & 59.3 & 9 & Kulonprogo & 85.2 \\
\hline 2 & Bukittinggi & 70.4 & 10 & Pacitan & 40.7 \\
\hline 3 & Padang & 92.6 & 11 & Magetan & 77.8 \\
\hline 4 & Wonogiri & 81.5 & 12 & Banjar & 77.8 \\
\hline 5 & Boyolali & 81.5 & 13 & Banjar Baru & 66.7 \\
\hline 6 & Salatiga & 74.1 & 14 & $\begin{array}{l}\text { Lentral } \\
\text { Lombok }\end{array}$ & 63.0 \\
\hline 7 & Karanganyar & 66.7 & 15 & East Lombok & 66.7 \\
\hline 8 & $\begin{array}{l}\text { Gunung } \\
\text { Kidul }\end{array}$ & 74.1 & 16 & Ambon & 48.1 \\
\hline \multicolumn{5}{|l}{} \\
\end{tabular}

Based on Table 8 above, it can be seen that from the 16 regencies/cities, the average program achievement of management for inclusion working group and grand design of inclusive education development was $70.4 \%$. Padang City had the highest achievement $(92.6 \%)$ while Pacitan Regency had the lowest achievement (40.7\%).

\section{Program of Inaugurating Programs as Inclusive} Provinces/Regencies/Cities

Program of Inaugurating Programs as Inclusive Provinces/Regencies/Cities is presented in Table 9.

TABLE IX. Program of InAUgurating Programs as InClusive PROVINCES/REGENCIES/CITIES

\begin{tabular}{|l|l|l|l|l|l|}
\hline No & $\begin{array}{c}\text { Regency/ } \\
\text { City }\end{array}$ & $\begin{array}{c}\text { Achieve- } \\
\text { ment }(\%)\end{array}$ & No & $\begin{array}{c}\text { Regency/ } \\
\text { City }\end{array}$ & $\begin{array}{c}\text { Achieve- } \\
\text { ment (\%) }\end{array}$ \\
\hline 1 & $\begin{array}{l}\text { Payakum- } \\
\text { buh }\end{array}$ & 100.0 & 9 & Kulonprogo & 100.0 \\
\hline 2 & Bukittinggi & 100.0 & 10 & Pacitan & 55.6 \\
\hline 3 & Padang & 100.0 & 11 & Magetan & 100.0 \\
\hline 4 & Wonogiri & 100.0 & 12 & Banjar & 77.8 \\
\hline 5 & Boyolali & 88.9 & 13 & Banjar Baru & 66.7 \\
\hline 6 & Salatiga & 100.0 & 14 & $\begin{array}{l}\text { Central } \\
\text { Lombok }\end{array}$ & 66.7 \\
\hline 7 & Karanganyar & 88.9 & 15 & East Lombok & 100.0 \\
\hline 8 & $\begin{array}{l}\text { Gunung } \\
\text { Kidul }\end{array}$ & 100.0 & 16 & Ambon & 100.0 \\
\hline \multicolumn{7}{|l|}{ Average =90.3\% } & & & \\
\hline
\end{tabular}

Based on Table 9 above, it can be seen that of the 16 regencies/cities as the sample of the study, the average program achievement of the inaugurating program as an inclusive province/ regency/city was $90.3 \%$. Several regencies/cities have reached $100 \%$ in this program, but Pacitan Regency had the lowest achievement $(55.6 \%)$.

Overall, the implementation of inclusive education at the Working group level in Regencies/Cities can be presented in Table 10, below:

TABLE X. IMPLEMENTATION OF INCLUSIVE EDUCATION AT THE WORKING GROUP LEVEL

\begin{tabular}{|l|l|}
\hline \multicolumn{1}{|c|}{$\begin{array}{c}\text { The Implementation of Inclusive Education at } \\
\text { the Working group level }\end{array}$} & \multicolumn{1}{|c|}{ Average } \\
\hline $\begin{array}{l}\text { Human Resource of Inclusive Education Organizer } \\
\text { Capacity Development Program }\end{array}$ & $73.20 \%$ \\
\hline $\begin{array}{l}\text { Program on Policy and Regulation on the } \\
\text { Implementation of Inclusive Education }\end{array}$ & $70.00 \%$ \\
\hline $\begin{array}{l}\text { Partnership Development Program through } \\
\text { Network Strengthening }\end{array}$ & $75.40 \%$ \\
\hline $\begin{array}{l}\text { Inclusive Education Organizer Introductory } \\
\text { Program Strengthening }\end{array}$ & $76.40 \%$ \\
\hline Data, Information and Publication Center Program & $69.80 \%$ \\
\hline $\begin{array}{l}\text { Program for Structuring and Stusive Education Support Systems } \\
\text { Inclusive }\end{array}$ & $79.20 \%$ \\
\hline Documentation and Reporting Program & $70.40 \%$ \\
\hline $\begin{array}{l}\text { Program of Management for Inclusion Working } \\
\text { group and Grand Design for Inclusive Education } \\
\text { Development }\end{array}$ & $\mathbf{7 5 . 1 8 \%}$ \\
\hline $\begin{array}{l}\text { Program of Inaugurating Programs as Inclusive } \\
\text { Provinces/Regencies/Cities }\end{array}$ & $90.30 \%$ \\
\hline Average & $70 \%$ \\
\hline
\end{tabular}

To clarify the results of the study, the following is a description of the average achievement of the implementation of inclusive education at the Working Group level of Regencies/Cities in Indonesia.

Based on the results of the study, it was found that in the implementation and monitoring of Inclusive Education, the Regional Working group team have carried out the role in accordance with the criteria. The role done in implementing and monitoring inclusive education is an effort to support the implementation of inclusive education in Indonesia. The kinds of support for inclusive education that have been carried out by the Regency/City Working group are:

1) Human Resource of Inclusive Education Organizer Capacity Development Program, which includes:

- Socialization of Inclusive Education for School Principals (Elementary, Middle School, High School, Vocational High School)

- Inclusive Education Workshop/Training for regular school teachers (elementary, junior high, high school, vocational high school)

- Inclusive Education Training for Special Guidance Teachers

- Comparative Study of Inclusive Education for Teachers in other schools (outside the Province/Regency/City)

- Socialization of further studies in the field of special education for Inclusive Teachers 
- Inclusive Education Workshop for SLB Principals/ Teachers

- Delegation of delegates at the Seminar/Conference forum on Inclusive Education for Teachers

2) Program on Policy and Regulation on the Implementation of Inclusive Education, which includes:

- Preparation of regional regulations on Inclusive Education at the Provincial/Regency/City level

- Preparation of Governor's Regulation/Mayor's Regulation/Regent's Regulation on Inclusive Education

- Preparation of Governor/Mayor/Regent Circular Letter on Inclusive Education Policy

- Preparation of Guidelines/Minimum Service Standards for Inclusive Education at the Provincial/Regency/City level

- Allocated regional expenditure income budget for Inclusive Education

3) Partnership Development Program Through Network Strengthening, which includes:

- The involvement of stakeholders across SKPD/related offices in the implementation of Inclusive Education in the region

- Collaboration with other parties (Universities, NGOs, Hospitals, Health Centers, Business World, etc.) in Inclusive Education.

- Utilization of print and electronic media in the development of Inclusive Education.

- Establishment of the Inclusive School Forum/Association

- Establishment of the Special Guidance Teacher Association/Forum

4) Inclusive Education Organizer Introductory Program, which includes:

- Determination of piloting school organizers of Inclusive Education (elementary, junior high, high school, vocational high school)

- Financing assistance/Education Facilities to inclusive education piloting school

- Evaluation and coaching of piloting schools by the agency/Working group

5) Data, Information and Publication Center Program, which includes:

- Data Collection of Children with Special Needs (ABK) of school age at the Provincial / Regency / City level who have and have not gone to school.

- Data Collection of SLB and Inclusion Schools at the Provincial/Regency/City level.

- Preparation and Establishment of special Web for Provincial/Regency/City Inclusive Education.
- Issuance of Inclusive Education Information Media by Provincial/District/City Working groups (Magazines, Bulletins, Leaflets, Brochures, CDs, etc.)

- Inclusive Education Exhibition at the Provincial/District/City level

- Organizing discussion/consultation and education forums on inclusive education.

6) Program for Structuring and Strengthening Inclusive Education Support Systems, which includes:

- Establishment and management of special schools and/ or other institutions as an Inclusive Education Resource Center.

- Provision of special financial assistance for Resource Center activities

- Evaluation and guidance of the Resource Center by the Agency/Inclusion Working group

- The existence of a Resource Center supported by a Letter of Determination/Appointment by the authorized Office.

7) Documentation and Reporting Program, which includes:

- The Inclusion Working group conducting documentation of all inclusive education activities in an orderly manner.

- The Inclusion Working group compiling reports on the progress of inclusive education in its regions for the Regional Government and the Central Government periodically.

8) Program of Management for Inclusion Working group and Grand Design for Inclusive Education Development, which includes:

- Inclusion working group developing Grand Design for the development of inclusive education at the Provincial/Regency/City level.

- Inclusion working group conducting the Grand Design of Inclusive Education Office/related SKPD.

- Grand Design of Inclusive Education determined by a Decree by the competent authority.

- The inclusion of Provincial/Regency/City working groups reinforced by the Governor's decree (for the Provincial level), Regent/Mayor's decree (for the Regency/ City level).

- Issuance, printing, and distribution of guidelines and/or instruments related to the implementation of inclusive education.

- Inclusion working groups with special secretariat office/ facilities

- Inclusion working groups equipped with clear organizational structures and work procedures 
- Inclusion working groups getting periodic support from operational costs from the Province/Regency/City

- The inclusion working group existance and engaging its duties and functions to update.

9) Program of Inaugurating Inclusive Provinces/Regencies/Cities:

- Local Government decided as Inclusive Province/Regency/City.

- Declaration as Inclusive Province/Regency/City confirmed in the form of a Decree by the Regional Leader.

- The declaration as Inclusive Province/Regency/City involving all officials and leaders of the SKPD and the stakeholder community.

\section{CONCLUSION}

Based on the results of the discussion, it can be concluded that the implementation of inclusive education at the Working Group level of the Regency/City has been carried out well.
This is indicated by the average score of the implementation of the results which is $75.18 \%$ considered as a good category.

\section{REFERENCES}

[1] Sunaryo, Manajemen Pendidikan Inklusif (Konsep, Kebijakan, dan Implementasinya dalam Perspektif Pendidikan Luar Biasa). Bandung: Jurusan PLB FIP UI, Universitas Pendidikan Indonesia, Bandung, Feb. 2009.

[2] Direktorat Pembinaan Pendidikan Khusus dan Layanan Khusus, Petunjuk teknis pengelolaan belanja bantuan khusus sekolah penyelenggara program pendidikan inklusif Dikmen tahun 2013. Jakarta: Direktorat Jenderal Pendidikan Menengah, 2013.

[3] Republik Indonesia, Peraturan Menteri Pendidikan Nasional No. 79 Tahun 2009 tentang Pendidikan Inklusif bagi Peserta Didik yang Memiliki Kelainan dan Memiliki Potensi Kecerdasan dan/ atau Bakat Istimewa. Jakarta: Permendiknas, 2009.

[4] Republik Indonesia, Surat Edaran Dirjen Manajemen Pendidikan Dasar dan Menengah, Kemendiknas No. 380/C.C6/MN/2003. Jakarta: Didasmen Depdiknas, 2003.

[5] Suaidinmath. (2010). Supporting System ofInclusive Education. [Online]. Available: http://www.suaidinmath.wordpress.com/2010/05/08/sistem-dukunganpendidikan-inklusif/

[6] S. J. Salend, Creating Inclusive Classroom. Effective and Reflective Practice. New Jersey: Pearson Education, 2011. 